\title{
Compact Integrated Bluetooth UWB Antenna with Quadruple Bandnotched Characteristics
}

\author{
Rekha Labade*, Shankar Deosarkar**, Narayan Pisharoty*** \\ **** Centre for Radio Science Studies, SymbiosisInternational University, Lavale, Pune 412115, India \\ *** Babasaheb Ambedkar Technological Institutes, Lonere, India
}

\section{Article Info \\ Article history: \\ Received Apr 21, 2015 \\ Revised Jul 21, 2015 \\ Accepted Aug 5, 2015 \\ Keyword: \\ Bluetooth \\ Dual band \\ Quadruple band notch \\ Time domain analysis \\ Ultrawideband (UWB)}

\begin{abstract}
In this paper, a compact printed dual band antenna for Bluetooth and UWB applications with Wi-MAX $(3.3-3.7 \mathrm{GHz})$, C-band satellite downlink (3.7GHz-4.2GHz), WLAN $(5.15-5.825 \mathrm{GHz})$ and DSRC $(5.50-5.925 \mathrm{GHz})$ band notched characteristics is proposed and investigated. By etching two half wavelength L-shaped slots in the radiating patch and an inverted Ushaped slot in the microstrip feed line the quadruple band notched characteristics are obtained. Further, by embedding quarter wavelength parasitic strip at the two edges of U-shaped radiating patch the dual band characteristic with desired bandwidth is obtained. The proposed antenna is designed and fabricated on a FR4 substrate with dimensions of $24 \times$ $35 \mathrm{~mm}^{2}$ that operates over a 2.4 to $11 \mathrm{GHz}$ with $\mathrm{S} 11 \leq-10 \mathrm{~dB}$ except over notch bands of $3.3-3.7 \mathrm{GHz}, 3.7-4.2 \mathrm{GHz}, 5.15$ to $5.625 \mathrm{GHz}$ and $5.625-6$ $\mathrm{GHz}$. Directional pattern in E-plane and nearly omnidirectional pattern in $\mathrm{H}$ plane are observed over a UWB band except at desired band-notched frequencies. Less variations in group delay and pulse deformation shows good time domain characteristics. In addition, the structure exhibits stable gain over the desired band.
\end{abstract}

Copyright (c) 2015 Institute of Advanced Engineering and Science. All rights reserved.

\section{Corresponding Author:}

Rekha Labade,

Departement of Electronics and Telecommuncation Engineering,

Symbiosis Institute of Technology, India

Email: rplabade@gmail.com

\section{INTRODUCTION}

Since 2002, after the declaration of unlicensed free frequency band of $7.5 \mathrm{GHz}(3.1 \mathrm{GHz} \sim 10.6 \mathrm{GHz})$ for ultrawideband (UWB) communication by Federal Communication Commission (FCC) [1], the UWB antenna became more popular. UWB antennas are most widely used in UWB systems because of its attractive features such as light weight, small size, low profile, low cost and higher data rate. Various applications of UWB antenna such as imaging, remote sensing, location tracking, sensor networks and medical attracted industry people and researchers towards design of UWB antenna. Numerous designs of UWB antenna have been reported in [2]-[5].However the existing narrowband wireless communication system such as 3.3 to $3.7 \mathrm{GHz}$ (Wi-MAX), 3.7-4.2 GHz (C-band satellite), 5.15 to $5.825 \mathrm{GHz}$ (WLAN) ,7.25-7.75 GHz (X-band satellite communication system) and $8.025-8.4 \mathrm{GHz}$ (ITU-band) causes potential interferences to the UWB systems operating over $3.1-10.6 \mathrm{GHz}$. UWB antenna is the most important element of UWB system and should provide a band notched characteristics to avoid the potential interferences of the forementioned band.

Interferences of these narrow band systems with UWB system can be eliminated with the use of filters which leads to increased size, cost and complexity of UWB system. Design of the UWB antenna with band notched characteristics is the effective and simple method to avoid the interference. Two major limitations of UWB antenna with multiple band notch functions are mutual coupling of multiband rejection element and space restrictions in the compact UWB antenna [6]. Several different techniques have been 
proposed and reported in literature to band notch single and multiple frequency bands [7]-[12]. In [7] crescent slot, U-slot [8] and compact coplanar waveguide (CPW) resonant cell (CCRC) [9] are used to realize single band-notched function. In [10] two nested c-shaped stubs gives dual notched band, interdigital capacitance loading loop resonator (IDCLLR) generates dual notched bands [CLL] in [11]. In [13] composite resonator with multiple resonant characteristics is used for obtaining triple band notched characteristics. Bluetooth Special Interest Group (SIG) in 2006 selected Wi-Media Alliance multiband orthogonal frequency division multiplexing (MB-OFDM) version of UWB, which could be integrated with Bluetooth wireless technology [14].This license free frequency band is integrated with the another license free UWB frequency band to facilitate the advantages of both Bluetooth and UWB frequency band for different applications in limited available space. Dual band antenna operating in Bluetooth and UWB proposed by [15]-[16] but without band notch characteristics. The UWB antenna with integrated Bluetooth and band-notched characteristics is investigated in [17]. L-shaped stubs of quarter wavelength placed in the ground plane near feed line and besides the radiating patch to create a resonance at Bluetooth and dual band notching respectively in [18].

In this paper a simple, compact, microstrip feed printed dual band antenna for Bluetooth and UWB applications with Wi-Max \& C-band satellite down link and WLAN \& DSRC (dedicated short range communication) quadruple band notched characteristics is proposed. The proposed antenna consists of a Ushaped radiating element feed by a $50 \Omega$ microstrip line with modified ground plane. A pair of L-shaped slots in the radiating patch and inverted U-shaped slot in feed line is etched to obtain the 3.3-4.2GHz and 5.15$6 \mathrm{GHz}$ band notched characteristics respectively. Two parasitic elements at the edge of the U-shaped radiator are used to resonate at $2.45 \mathrm{GHz}$ frequency. The proposed antenna is designed, simulated, fabricated and tested. Simulation is carried out using method of moments based electromagnetic simulation software CAD FEKO (6.2 suite).

\section{ANTENNA DESIGN}

The geometry of the proposed dual band UWB antenna with band notched characteristics is illustrated in Figure 1. The proposed antenna is designed on a FR4 dielectric substrate with dielectric constant $\left(\varepsilon_{\mathrm{r}}\right)=4.4$, loss tangent $(\tan \delta)=0.02$ with thickness of $1.6 \mathrm{~mm}$.U-shaped radiating patch is feed by a printed microstrip line on the top side of the substrate and printed modified ground plane with a size of $\mathrm{W}_{\text {sub }} \times \mathrm{L}_{\text {gnd }}\left(24 \times 10 \mathrm{~mm}^{2}\right)$ on the bottom side of the substrate. To obtain the $50 \Omega$ characteristics impedance, width $\left(\mathrm{w}_{\mathrm{f}}\right)$ and length $\left(\mathrm{l}_{\mathrm{f}}\right)$ of microstrip fed line is fixed at $3 \mathrm{~mm}$ and $11 \mathrm{~mm}$ respectively. The total dimension of the proposed antenna is $24 \times 35 \mathrm{~mm}^{2}$.

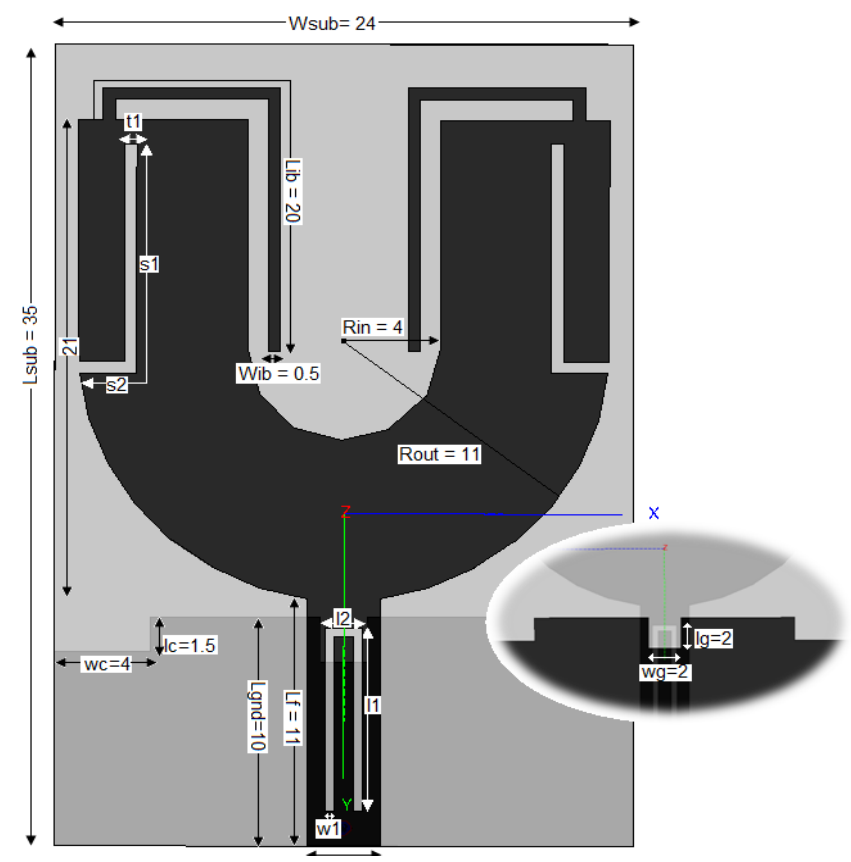

Figure 1. Geometry of Proposed antenna 
Table 1. Optimum Dimensions of Proposed Antenna (All Dimensions are in $\mathrm{mm}$ )

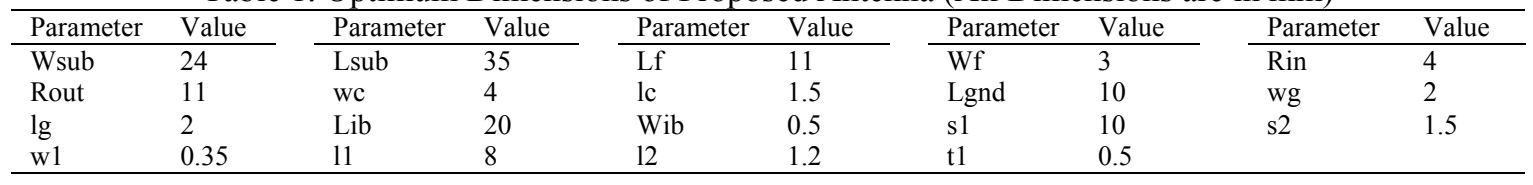

The structure is evolved from the semicircular monopole antenna to U-shaped radiator and the proposed one. The lower band edge frequency ' $\mathrm{f}_{1}$ ' of UWB has been determined using formulas [4] as given in Equation (1).

$$
\mathrm{f}_{\mathrm{l}}=\frac{7.2}{\left\{\left(\mathrm{~L}+\mathrm{R}_{\text {out }}+\mathrm{L}_{\mathrm{f}}\right) * \mathrm{k}\right\}}
$$

Where, $\mathrm{L}=$ effective length of the circular monopole, $\mathrm{k}=1.15$ is taken empirically for a dielectric substrate with $\varepsilon_{\mathrm{r}}=4.4$ and dielectric thickness of $1.6 \mathrm{~mm}, \mathrm{R}_{\mathrm{out}}=11 \mathrm{~mm}$.

Further, two rectangular slots are cut from the edges of the modified ground plane to enhance the impedance matching in UWB frequency band. To prevent the interferences of Wi-MAX \& C-band satellite downlink frequency and WLAN\& DSRC narrow band systems, a pair of L-shapedslot in the radiating patch and an inverted U-shaped slot is etched in the microstrip feed line are etched respectively. The lengths of the slot has been taken about half the guided wavelength:

$$
\begin{aligned}
& \mathrm{L}_{\text {SLOT }}=\frac{\lambda \mathrm{g}}{2} \\
& \lambda_{\mathrm{g}}=\frac{\lambda_{0}}{\sqrt{\varepsilon_{\text {reff }}}}
\end{aligned}
$$

Where, $\varepsilon_{\text {reff }}=$ effective dielectric constant $=\left(\varepsilon_{\mathrm{r}}+1\right) / 2, \lambda_{0}=$ free space wavelength $=\mathrm{C}_{0} / \mathrm{f}_{\mathrm{r}}, \mathrm{C}_{0}=$ velocity of light signal and $\mathrm{f}_{\mathrm{r}}=$ centre frequency of the notch band.

The total length of L-shaped pair, Lslot $=2\left(\mathrm{~s}_{1}+\mathrm{s}_{2}+\mathrm{t}_{1}\right)=24.6 \mathrm{~mm}$ is etched in the radiating patch to generate a notch for first two consecutive bands centered at $3.7 \mathrm{GHz}(3.3-3.7 \mathrm{GHz} \& 3.7-4.2 \mathrm{GHz})$ and second inverted U-slot Lslot $_{2}=\left(2 \mathrm{l}_{1}+\mathrm{l}_{2}+2 \mathrm{t}_{2}\right)=16.52 \mathrm{~mm}$ is etched in the microstrip feed line to generate a next consecutive notch bands centered at $5.5 \mathrm{GHz}(5.15-5.825 \mathrm{GHz} \& 5.50$ to $5.925 \mathrm{GHz})$. The optimized dimensions of slot 1 and $\mathrm{slot}_{2}$ are $24 \mathrm{~mm}$ and $19.1 \mathrm{~mm}$ respectively.

By positioning the two rectangular parasitic elements from upper edge to centre of U- patch, desired dual-band characteristics for Bluetooth and UWB operations have been achieved. Placing the rectangular parasitic elements to the centre portion of radiating U-shaped patch, makes the antenna compact and symmetric one. Two rectangular parasitic elements resonate over Bluetooth frequency band while U-shaped radiating element resonates over UWB band. The total length ' $\mathrm{L}_{\mathrm{ib}}$ ' of the two parasitic elements is about quarter wave long at centre Bluetooth frequency band ' $\mathrm{f}_{\mathrm{ib}}$ '.

$$
\mathrm{L}_{\mathrm{ib}}=\frac{\mathrm{C}_{0}}{4 \mathrm{f}_{\mathrm{ib}}}
$$

The optimized dimensions of Bluetooth parasitic strip are width ' $\mathrm{W}_{\mathrm{ib}}$ ' $=0.5 \mathrm{~mm}$ and length ' $\mathrm{L}_{\mathrm{ib}}$ ' $=20 \mathrm{~mm}$.

The performance of U-shaped dual band antenna with quadruple band notched characteristic depends on different parameters such as inner $\left(R_{i n}\right)$ and outer radius $\left(R_{\text {out }}\right)$ of semi-annular ring, gap (' $g$ ') between the radiating patch and ground plane, length $\left(l_{c}\right)$ and width $\left(\mathrm{w}_{\mathrm{c}}\right)$ of corner cut slots in the modified ground plane, width $\left(\mathrm{t}_{1}\right)$ and length $\left(\mathrm{s}_{1}+\mathrm{s}_{2}\right)$ of the L-shaped slots in the radiating patch, length $\left(\mathrm{l}_{1}+\mathrm{l}_{2}\right)$ and width $\left(\mathrm{w}_{1}\right)$ of the inverted U-shaped slots in the microstrip feed line, length $\left(\mathrm{L}_{\mathrm{ib}}\right)$ and width $\left(\mathrm{W}_{\mathrm{ib}}\right)$ of the parasitic element operating at Bluetooth frequency band.

Insight of the antenna characteristics is given by conducting the parametric study of important parameters. Two L-shaped slot having length $\mathrm{L}_{\text {slot } 1}=23 \mathrm{~mm}$ is etched in U-shaped radiating patch to create a notch band at centre frequency of $3.75 \mathrm{GHz}(3.3-4.2 \mathrm{GHz})$. Effect of length and width variations of these slot is depicted in Figure 2(a) and (b) respectively. Figure 2(a) shows that with increase in the length of the slot, resonant frequency shifts to the left side of the notch band because increase in the slot length decreases the resonance frequency. While increase in the slot width increases bandwidth of notched band without affecting the UWB characteristics as illustrated in Figure 2(b). 


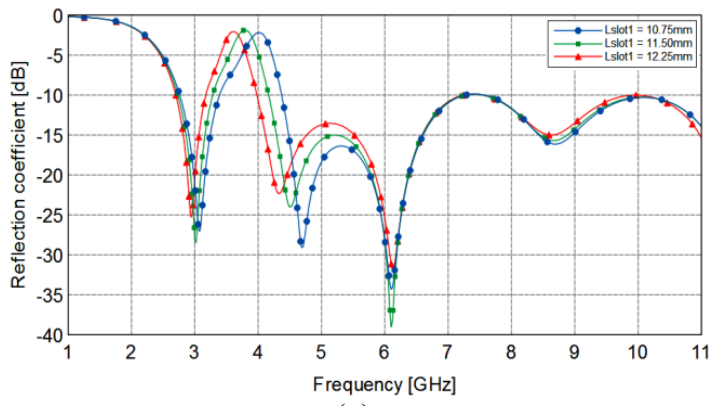

(a)

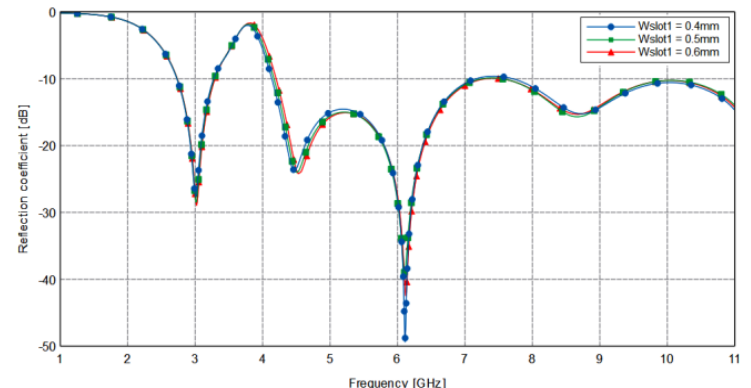

(b)

Figure 2. Simulated reflection coefficient of Wi-Max \& C-band satellite downlink band-notched UWB antenna for (a) different slot length ' $\mathrm{L}_{\text {slot1 }}$ ' (b) different slot length ' $\mathrm{W}_{\text {slot1 }}$ '

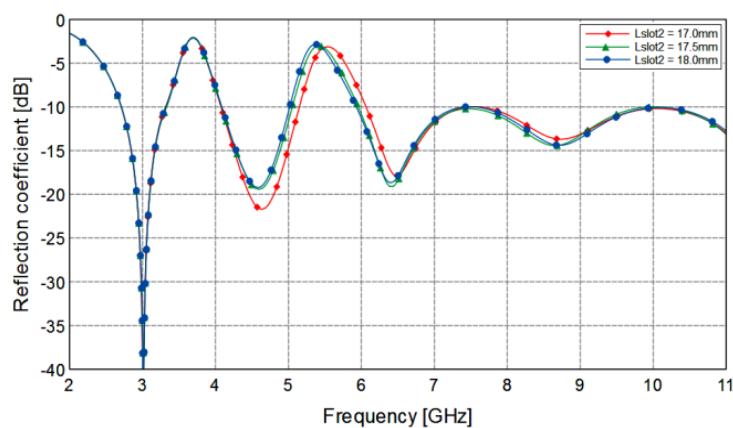

(a)

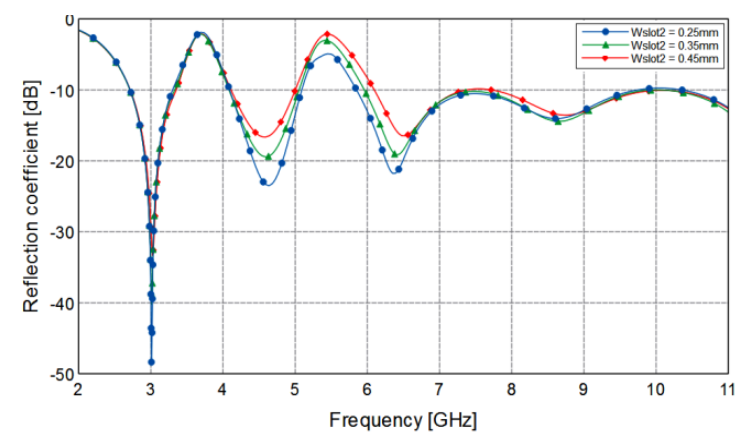

(b)

Figure 3. Simulated reflection coefficient of dual band-notched UWB antenna for (a) different slot length ' $\mathrm{L}_{\text {slot2}}$ ' of inverted U- slot (b) different slot width ' $\mathrm{W}_{\text {slot2 }}$ ' of inverted U -slot

Similar investigations are observed by varying the length and width of the inverted U-slot in the feed line to generate a notch band centered at $5.5 \mathrm{GHz}(5.15-6 \mathrm{GHz})$. From the above analysis we can conclude that, length and width of slots mainly controls the performance of notched-band antenna. Simulated return loss of inverted U-shaped slot in the feedline for length and width variations is depicted in Figure 3(a) and (b).
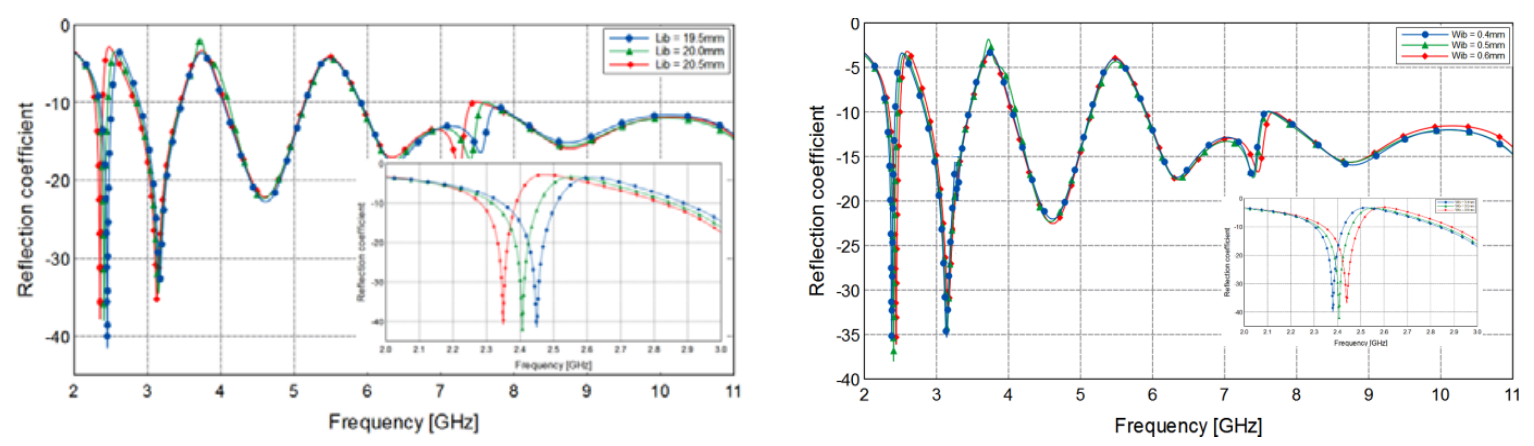

Figure 4. Simulated reflection coefficient of Integrated Bluetooth and band-notched UWB antenna for (a) different parasitic element length ' $\mathrm{L}_{\mathrm{ib}}$ ' (b) different parasitic element width ' $\mathrm{W}_{\mathrm{ib}}$ '

Two quarter wavelength parasitic strip resonating at centre Bluetooth frequency are embedded at the two edges of U-shaped radiating patch at minimum current position of UWB to ensure the minimum coupling between UWB and Bluetooth element. The length of two parasitic element is calculated using Equation (3). Total length of theBluetooth element $\mathrm{L}_{\mathrm{ib}}=20 \mathrm{~mm}$, which is less than the calculated length due to 
the dielectric substrate, fringing effect and mutual coupling between U-shaped patch and Bluetooth parasitic elements [19]. Simulated reflection coefficient for length and width variations of the Bluetooth parasitic element is shown in Figure 4. The length ' $\mathrm{L}_{\mathrm{ib}}$ ' of Bluetooth element decides the resonance frequency. Resonance frequency shifts to the lower side of the plot with increase in length as shown in Figure 4(a). Variations in ' $\mathrm{W}_{\mathrm{ib}}$ ' affects the bandwidth as well as resonance frequency. As ' $\mathrm{W}_{\mathrm{ib}}$ ' increases impedance bandwidth of Bluetooth band increases and resonance frequency of Bluetooth decreases as depicted in Figure 4(b).

\section{RESULTS AND DISCUSSIONS}

Surface current distributions are used to analyse the effect of Bluetooth parasitic strip, the L-shaped slots in the radiating patch and an inverted U-shaped slot in feed line. At $2.45 \mathrm{GHz}$, maximum current concentration is observed along parasitic Bluetooth element showing that these elements are primarily responsible for producing resonance at $2.45 \mathrm{GHz}$, while U-shaped radiating patch appears to be non-radiating at this frequency. Intense current concentration around the $\mathrm{L}$ and Inverted U-shaped slots at $3.75 \mathrm{GHz}$ and $5.5 \mathrm{GHz}$ respectively shows the effect of band notching and independent control of individual notched band. Other than Bluetooth and notched frequency bands maximum current concentration is observed on the edges of patch showing UWB behaviour of antenna.

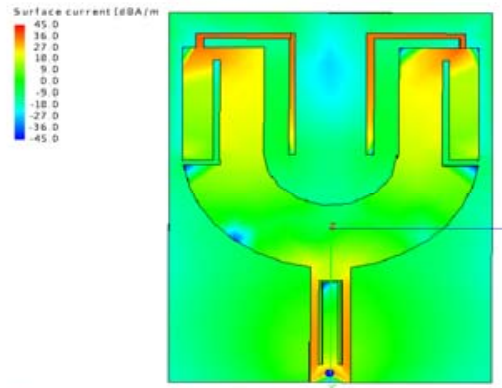

(a)

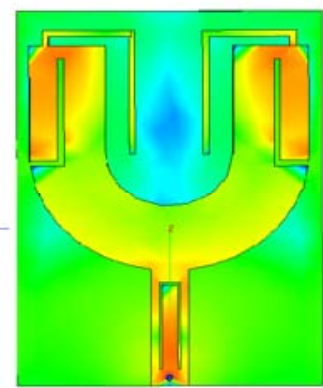

(b)

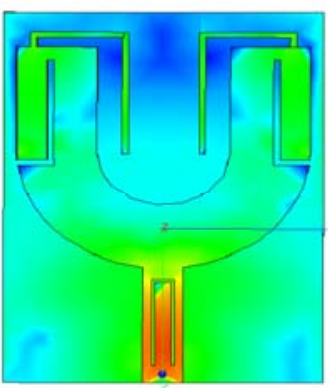

(c)

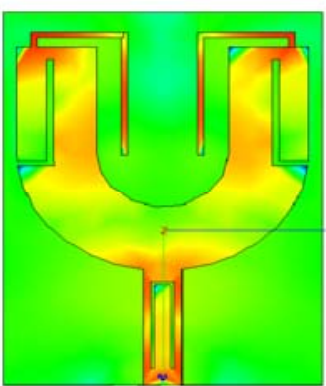

(d)

Figure 5. Surface current distribution of integrated Bluetooth and band notched UWB antenna at (a) $2.45 \mathrm{GHz}$ (b) $3.5 \mathrm{GHz}$ (c) $5.5 \mathrm{GHz}$ (d) $7.5 \mathrm{GHz}$

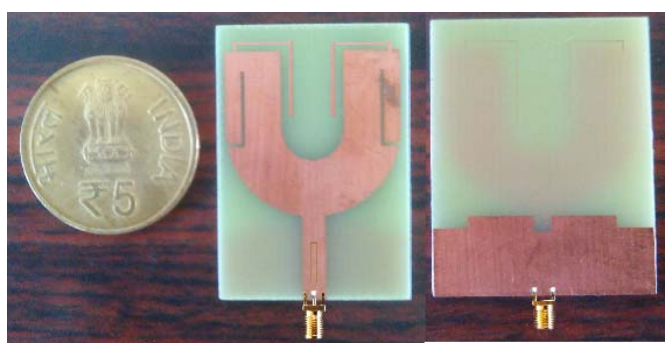

Figure 6. Fabricated prototypes of the proposed antenna

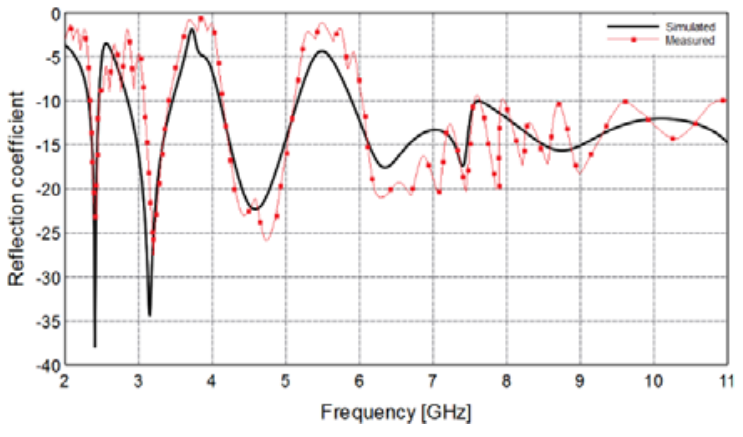

Figure 7. Simulated and measured $\mathrm{S}_{11}$ of the proposed antenna

The proposed integrated Bluetooth, band notched UWB antenna was successfully fabricated as shown in Figure 6. The impedance bandwidth was measured using an Agilent Field-fox N9916A vector network analyzer as depicted in Figure 7. Small discrepancy between simulated and measured results was observed. This discrepancy is due to the use of SMA connector and cable through which SMA connector of the antenna connected to VNA for measurement of reflection coefficient while during simulation using CAD FEKO antenna is excited by a wire port having $50 \Omega$ impedance for all frequencies. Measured results shows the proposed antenna integrates Bluetooth frequency band from 2.4-2.5GHz while rejects Wi-MAX\& C-band satellite downlink $(3.3 \mathrm{GHz}-4.2 \mathrm{GHz})$ and WLAN \& DSRC band $(5-6 \mathrm{GHz})$, while providing the wide impedance bandwidth from $3.1 \mathrm{GHz}$ to $11 \mathrm{GHz}$.Radiation patterns of antenna across E-plane and H-planes at

Compact Integrated Bluetooth UWB Antenna with Quadruple Bandnotched Characteristics (Rekha Labade) 
2.4 GHz, 4.5 GHz and 7GHz are illustrated in Figure 8(a) and (b).Directional pattern in E-plane and omnidirectional pattern in H-plane are observed over a UWB frequency band except at the notched bands frequencies.
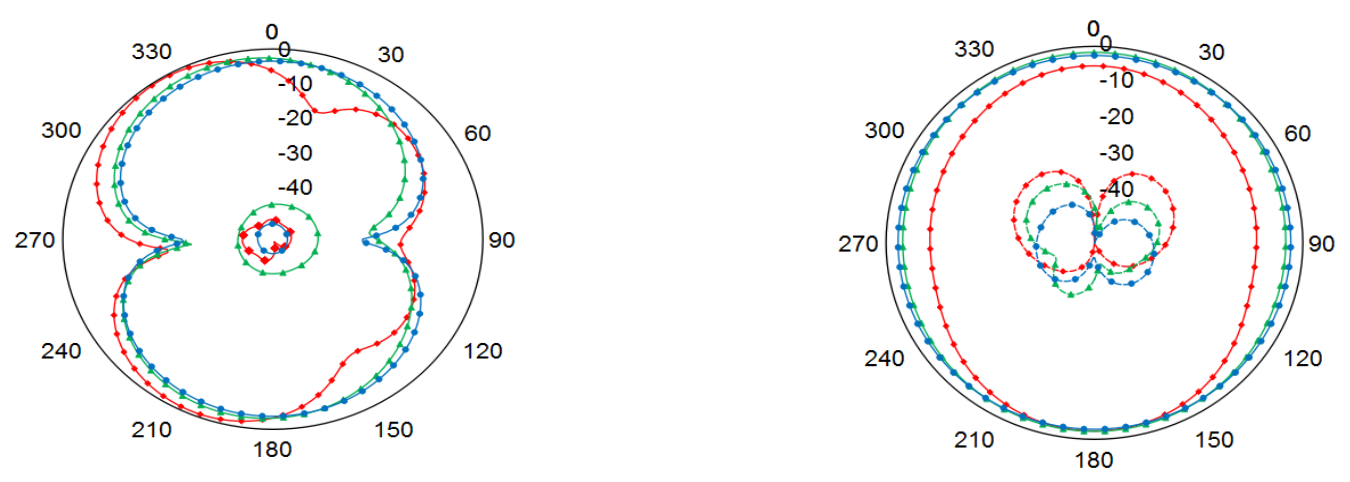

Figure 8. Radiation pattern of the proposed antenna for (a) E-plane and (b) H- plane at sampling frequencies $2.4 \mathrm{GHz}, 4.5 \mathrm{GHz}$ and $7 \mathrm{GHz}$

Average radiation efficiency across the UWB frequency band is about $75 \%$ and at notched band $10 \%$ drop in the efficiency from $3.3-4.2 \mathrm{GHz}$ and $5.15-6 \mathrm{GHz}$ clearly indicates the WiMax\& C-band satellite downlink and WLAN \& DSRC band rejection capability of the proposed antenna. A $10 \%$ drop in the efficiency is due to less radiation of antenna at aforementioned notched frequency bands. Similarly almost stable gain over UWB except notched bands is observed as shown in Figure 9.

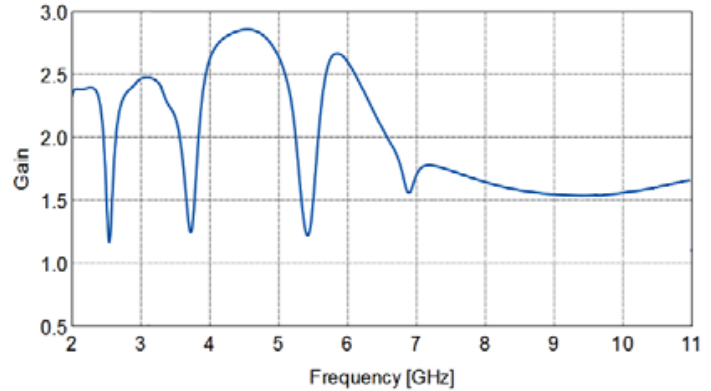

Figure 9. Simulated gain of the proposed antenna

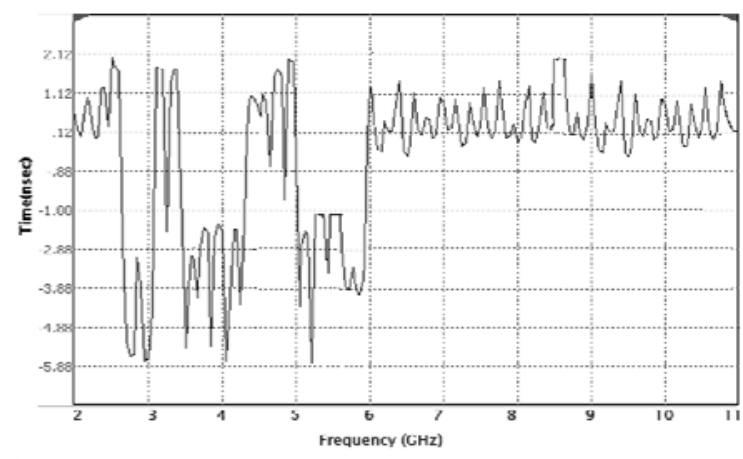

Figure 11. Measured group delay of the proposed antenna

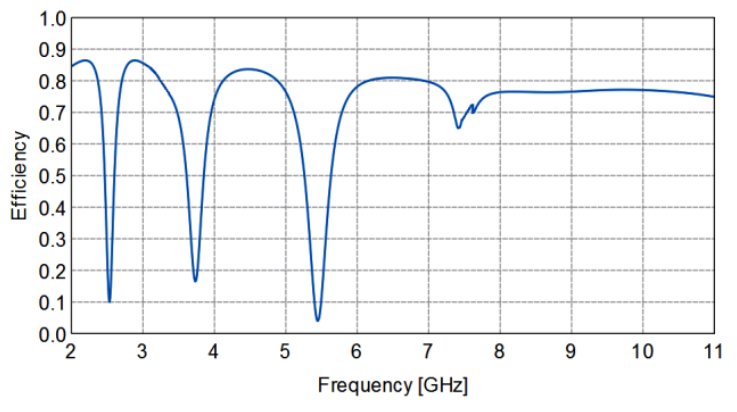

Figure 10. Efficiency of the proposed antenna

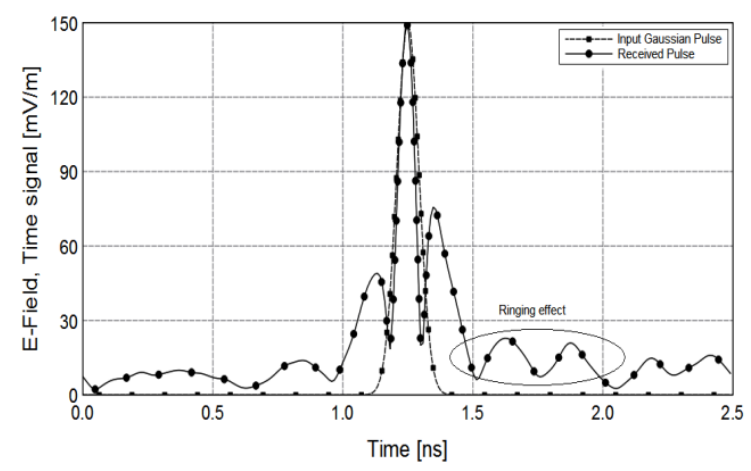

Figure 12. Time Domain Analysi 
Time domain characteristics of UWB antenna is given in terms of pulse spreading and group delay performance. Good time domain performance is an important requirement of UWB antenna [20]-[21]. Time delay of impulse signal at different frequencies gives the group delay. Two identical antennas are placed $400 \mathrm{~mm}$ apart from each other for measurement of group delay. Less variation in group delay is observed over UWB frequency band except notched frequency band. Group delay of proposed UWB antenna is depicted in Figure 11. Except notched frequency bands less variation in the group delay are observed over entire UWB band. Pulse spreading behavior of proposed antenna is obtained using time domain analysis of CAD FEKO [24]. Excited Gaussian pulse and received signal for Integrated Bluetooth and band notched UWB monopole antenna is shown in Figure 12. A small ringing in the received pulse is observed.

Table 1. Comparison between reported integrated Bluetooth and Band notch UWB antennas

\begin{tabular}{|c|c|c|c|c|c|}
\hline Parameter & Ref.[14] & Ref.[22] & Ref.[ 18] & Ref[23] & Proposed Work \\
\hline $\begin{array}{l}\text { UWB operating } \\
\text { frequency }\end{array}$ & $3.1-10.6 \mathrm{GHz}$ & $3.1-10.6 \mathrm{GHz}$ & $\begin{array}{l}3.1-11.434 \\
\mathrm{GHz}\end{array}$ & $3.04-10.8 \mathrm{GHz}$ & $3.1-11 \mathrm{GHz}$ \\
\hline $\begin{array}{l}\text { Bluetooth } \\
\text { frequency band }\end{array}$ & $2.4-2.5 \mathrm{GHz}$ & $2.4382 .495 \mathrm{GHz}$ & $2.18-2.59 \mathrm{GHz}$ & $2.33-2.5 \mathrm{GHz}$ & $2.4-2.5 \mathrm{GHz}$ \\
\hline $\begin{array}{l}\text { Number of } \\
\text { notched bands }\end{array}$ & $\begin{array}{l}\text { Two( CMMB } \\
\text { 2.856GHz and } \\
\text { WLAN 5.5GHz) }\end{array}$ & $\begin{array}{l}\text { Single(WLAN } \\
5.14 \mathrm{GHz} \text { to } \\
5.823 \mathrm{GHz})\end{array}$ & $\begin{array}{l}\text { Single (WLAN } \\
5.15-5.825 \mathrm{GHz})\end{array}$ & $\begin{array}{l}\text { Dual(Wi-Max:3.3- } \\
\text { 4.1GHz),WLAN(5- } \\
\text { 5.9GHz ) }\end{array}$ & $\begin{array}{l}\text { Quad (WiMAX,C- } \\
\text { band satellite } \\
\text { downlink,WLAN,DS } \\
\text { RC) }\end{array}$ \\
\hline Dielectric constant & 3.48 & 4.4 & 4.4 & 4.4 & 4.4 \\
\hline Thickness & 0.832 & 1.59 & 1.6 & 1.6 & 1.6 \\
\hline $\begin{array}{l}\text { Size(Lsub } \times \\
\text { Wsub) } \mathrm{mm}^{2}\end{array}$ & $39.75 \times 31.5$ & $52 \times 32$ & $50 \times 24$ & $41 \times 30$ & $35 \times 24$ \\
\hline
\end{tabular}

\section{CONCLUSION}

A compact dual band antenna for Bluetooth and UWB applications with band notched characteristics has been presented. To achieve the integrated Bluetooth characteristics two parasitic elements are placed at two edges of the U-shaped radiating patch and two L-shaped slots and Inverted U-shaped slots are etched in radiating patch and the microstrip feed line respectively to obtained quadruple band notched characteristics. It has been observed that by simply adjusting the length and width of the parasitic element and the slots, resonant frequency and bandwidth of integrated Bluetooth and notched band can be controlled.

\section{REFERENCES}

[1] First report and order, "Revision of part 15 of the commission's Rule Regarding UWB Transmission System, Federal Communication Commission, 2002.

[2] Soheil Radiom, Hadi Aliakbarian, Guy A. E. Vandenbosch, and Georges G. E. Gielen, "An Effective Technique for Symmetric Planar Monopole Antenna Miniaturization”, IEEE Transaction on Antennas And Propagation, Vol. 57, No. 10, pp. 2989-2996, 2009.

[3] Jihak Jung, Wooyoung Choi, and Jaehoon Choi, "A SmallWideband Microstrip-fed Monopole Antenna", IEEE Microwave And Wireless Components Letters, Vol. 15, No. 10, pp.v703-705, 2005.

[4] K. P. Ray, and Y. Ranga, "Ultrawideband Printed Elliptical Monopole Antennas", IEEE Transaction on Antennas And Propagation, Vol. 55, No. 4, pp. 1189-1192, 2007.

[5] Joanne Gomes, B. K. Mishra, "Performance Evaluation of UWB Wireless Link", International Journal of Information and Network Security (IJINS),Vol. 1, No. 3, pp. 188-199, 2012.

[6] Jie Xu, Kunming Dongya Shen, Xiupu Zhang, Ke Wu, "A Compact Disc UltrawideBand (UWB) Antenna With Quintuple Band Rejections", IEEE Antennas and Wireless Propagation Letters, Vol. 11, pp. 1517-1520, 2012.

[7] L. Akhoondzadeh-Asl, M. Fardis, A. Abolghasemi, and G. Dadashzadeh, "Frequency and Time Domain Characteristics of a Novel Notch Frequency UWB Antenna", Progress In Electromagnetic Research, Vol. 80, pp. 337-348, 2008.

[8] Young Jun Cho, Ki Hak Kim, Dong Hyuk Choi, Seung Sik Lee, and Seong-Ook Park, "A Miniature UWB Planar Monopole Antenna With 5-GHz Band-Rejection Filter and the Time-Domain Characteristics", IEEE Transactions On Antennas And Propagation, Vol. 54, No. 5, pp. 1453-1460, 2006.

[9] Shi-Wei Qu, Jia-Lin Li, and Quan Xue, A Band-Notched Ultrawideband Printed Monopole Antenna", IEEE Antennas and Wireless Propagation Letters, Vol. 5, pp. 495-498, 2006.

[10] R. Seyed Ramin Emadian, Changiz Ghobadi, Javad Nourinia, MirHamed Mirmozafari, and Javad Pourahmadazar, "Bandwidth Enhancement of CPW-Fed Circle-Like Slot Antenna With Dual Band-Notched Characteristic", IEEE Antennas And Wireless Propagation Letters, Vol. 11, pp. 543-546, 2012.

[11] Tong Li, Huiqing Zhai, Guihong Li, Long Li, and Changhong Liang,“Compact UWB Band Notched Antenna design using interdigital capacitance loaded loop resonator", IEEE Antennas And Wireless Propagation Letters, Vol. 11, pp. 724-727, 2012. 
[12] A. Boutejdar, A. A. Ibrahim, E. P. Burte, “A Compact Multiple Band-Notched Planer Antenna with Enhanced Bandwidth Using Parasitic Strip Lumped Capacitors and DGS-Technique”, TELKOMNIKA Indonesian Journal of Electrical Engineering, Vol. 13, No. 2, 2015.

[13] Xing Qun Qi, Hong-Chun Yang, D Kai Liu, and Yang Li, "Dual And Triband Notched Ultrawideband (UWB) Antennas using compact composite resonator", Progress in Electromagnetics Research Letters, Vol. 42, pp. 177$185,2013$.

[14] Law K. C., S. W. Cheung, and T. I. Yuk, "An integrated UWB and Bluetooth Antenna with dual Band-notched Characteristics", PIERS Proceedings, Suzhou, China, pp. 12-16.

[15] Rekha P. Labade, Shankar B. Deosarkar, Narayan Pisharoty, "Square Printed Monopole Antenna for Wireless Application", World Academy Of Science, Engineering and Technology, International Journal of Electrical, Electronics Science and Engineering, Vol. 8 No. 1, pp. 109-118, 2014.

[16] Harrington R. F., Mautz J. R., "Theory of characteristic modes for conducting bodies," IEEE Transactions on Antennas and Propagation, Vol. 19, No. 5, pp. 622-628, 1971.

[17] Zhao Q, S. X. Goang, W. Jiang, B. Yang, and J.Xie, "Compact wideslot Tri-band Antenna for WLAN/WiMax Applications”, Progress In Electromagnetic Research, Vol. 18, pp. 9-18, 2010.

[18] Xianglong Liu, Yingzeng Yin, Pingan Liu, Junhui Wang, and Bin Xu, "A CPW-FED Dual Band-Notched Uwb Antenna With A Pair Of Bended Dual-L-Shape Parasitic Branches", Progress In Electromagnetics Research, Vol. 136, pp. 623-634, 2013.

[19] Sanjeev Kumar Mishra, Rajiv Kumar, Avinash Vaidya, and Jayanta Mukharjee, "Printed Fork-Shaped dual band Monopole Antenna for Bluetooth and UWB Applications with 5.5GHz WLAN Band Notched Characteristics", Progress in Electromagnetics Research C, Vol. 22, pp. 195-210, 2011.

[20] M. Abdollahvand, G. Dadashzadeh, and D. Mostafa, "Compact bandnotched Printed Monopole Antenna for WLAN Applications", IEEE Antennas And Wireless Propagation Letters, Vol. 9, pp1148-1151, 2010.

[21] Zi-Han Wu, Feng Wei, Xiao-Wei Shi, and Wen-Tao Li, "A Compact Quad Band-Notched UWB Monopole Antenna Loaded One Lateral L-Shaped Slot”, Progress In Electromagnetic Research, Vol. 139, pp. 303-315, 2013.

[22] Tapan Mandal, Shantanu Das, "Design of a microstrip fed Printed Monopole Antenna for Bluetooth and UWB Applications with WLAN Notch Band Characteristics", International Journal of RF and Microwave Computer Aided Design,Vol. 25, No. 1, pp. 66-74, 2015.

[23] Su Sandar Thwin, "Design and optimization of integrated Bluetooth and UWB antenna with dual Band-notched functions", International Journal of Computer Networks \& Communications (IJCNC), Vol. 4, No. 4, 2012.

[24] Feko Quarter, issue June, 2012.

\section{BIOGRAPHIES OF AUTHORS}

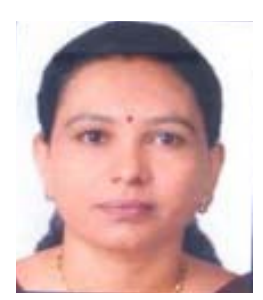

Rekha P Labadehas received her BE Degree in Electronics in 1994 from University of Pune, (M.S) ME(Electronics) in 2004 from BAMU, Aurangabad(M.S),India. Presently, she ispursuing Ph. D from Symbiosis International University. She is an assistant professor in Department Electronics and Telecommunication at Amrutvahini college of Engineering. She has 16 years of teaching experience. Her areas of interest are design of Microstrip antenna, Ultrawideband antenna and microwave engineering.

Email:rplabade@gmail.com

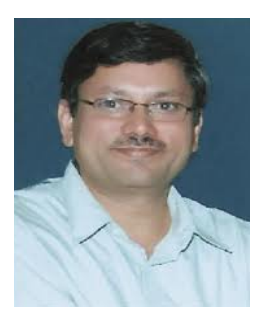

Dr. S. B. Deosarkarhas received BE Degree in Electronics in 1988 from Amravati University and his both M. Tech and Doctorate Degrees in the area of Microwave Communication in 1990 and 2004 respectively from S.G.G.S. Institute of Engineering and Technology, Nanded.He has 23 years of teaching experience at undergraduate and postgraduate level. He has been credited with about 35 research publications at the National and International level. Currently he is guiding five Research Scholars in the area of EMI / EMC and Microstrip Antenna Design.

E-mail: sbdeosarkar@yahoo.com

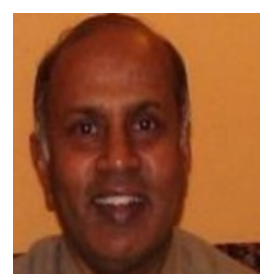

Dr. Narayan Pisharotyis working as a professor in Department Electronics and Telecommunication at Symbiosis Institute of Technology. He has 38 years of experience. His areas of interest are RFID Application in Bio Medical Engg, Alternate Energy Sources, and applications of microprocessor in Agriculture. At present he is guiding five Research Scholars.

E-mail: narayanp@sitpune.edu.in 